\title{
ЕНТОЛОМА НІФОІДЕ СZҮ ВЕСЕЛКА ЗВИЧАЙНА?-- ŁACINA I GREKA JAKO ŹRÓDŁO UKRAIŃSKICH NAZW GRZYBÓW WIELKOOWOCNIKOWYCH
}

\author{
Przemysław Jóźwikiewicz \\ Uniwersytet Wrocławski, Wrocław, Polska \\ ORCID: 0000-0002-3654-7724
}

\begin{abstract}
Streszczenie. Języki klasyczne są istotnym źródłem ukraińskiej terminologii mykologicznej i analizowanych w niniejszym artykule nazw grzybów makroskopijnych. Badania, których wyniki tu przedstawiono, dowodzą, iż wpływ, zwłaszcza łaciny, na ten kompleks słownictwa jest bardzo szeroki. Aż 75\% wszystkich nazw w badanej próbce stanowią struktury, których element główny to zapożyczenie właściwe o proweniencji głównie łacińskiej (np. Нектрія пеціuа). Nazw, których człon rodzajowy tworzył leksem ukraiński, jest ponad trzykrotnie mniej (wliczając w to także konstrukcje, których oba człony były stricte ukraińskie, np. Маслюк звичайний). Zupełnie odmiennie rysuje się struktura epitetów gatunkowych. Tu z kolei dominują leksemy rdzennie ukraińskie (w sumie niemal tysiąc jednostek, np. Антродія вербова) i kalki (ponad 500 jednostek, np. Головач келиховидний). W funkcji tej zapożyczenia występują raczej incydentalnie (nieco powyżej stu jednostek, np. Сироїжка Аврора), podobnie jak struktury hybrydalne (kilkadziesiąt przykładów, np. Дощяовик умбровий).
\end{abstract}

Słowa kluczowe: język ukraiński, łacina, greka, terminologia mykologiczna, nazwy grzybów makroskopijnych.

Konsekwencją rozpadu Cesarstwa Rzymskiego w 395 roku był nie tylko wieloaspektowy podział ówczesnej Europy, ale także późniejsza fragmentacja Słowiańszczyzny i jej funkcjonowanie w obrębie dwóch obszarów cywilizacyjnych i historyczno-kulturowych - Pax Slavia Romana i Pax Slavia Orthodoxa. $\mathrm{Na}$ ich styku znalazła się Ruś Kijowska, państwo pozostające w strefie wpływów bizantyjskich, religii prawosławnej i języka staro-cerkiewno-słowiańskiego. Upraszczając, po rozpadzie Rusi, jej podziale na mniejsze księstwa i nawale tatarskiej, część jej terytorium przeszła pod jurysdykcję Litwy, później Korony, a zatem znalazła się w kręgu oddziaływania świata kultury łacińskiej. Od tego czasu na tym obszarze wzrastała rola łaciny, choć należy pamiętać, że pierwsze latynizmy przenikały do języka staroruskiego począwszy od X-XI w.

Jak pisze Diana Wieczorek ,[...] конфигурацию Slavia Latina - Slavia Orthodoxa можно бы представить как Slavia Latina - Slavia Graeca". Wy- 
pada zgodzić się z tym zdaniem, jak również ze stwierdzeniem, że „На стыке латино-славянского и греческо-славянского миров и оказалась Украина. Если проследить всю культурную историю Украины, то можна убедиться в том, что она представляет собой особый, дихотомический мир, вписанный в каждую из культур. В латино-славянскую культуру - через польское посредничество, вернее, благодаря своим связям с польской культурой"1.

Kontaktom z Bizancjum Ruś/Ukraina zawdzięcza początki nauki - dzięki greckiemu osadnictwu na północnym wybrzeżu Morza Czarnego i bizantyjskim wpływom kulturowym rodząca się kultura ukraińska zyskała dostęp do tradycji antycznej, zaś sam wpływ greki na język ukraiński jest niezaprzeczalny. Obok języka staro-cerkiewno-słowiańskiego to właśnie greka stanowiła podstawę nauczania w pierwszych ośrodkach oświatowych na ziemiach ukraińskich, wzbogacając zasoby leksykalne kształtującej się ukraińszczyzny wraz z jej piśmiennictwem, na wielu płaszczyznach i w wielu wymiarach.

W jakim stopniu na język ukraiński wpłynęła natomiast łacina? Pytanie to wymagałoby niezwykle rozbudowanej odpowiedzi. Jej składowymi byłyby przede wszystkim informacje dotyczące sytuacji na ziemiach ukraińskich w wiekach XVI i XVII, a więc w okresie intensywnego rozwoju nauki i szkolnictwa, powstawania szkół brackich $\mathrm{w}$ wielu ośrodkach miejskich (m.in. Lwów, Halicz, Stryj, Jarosław, Kijów, Winnica, Łuck), powołania Kolegium Kijowsko-Mohylańskiego (przekształconego w Akademię w 1658 roku), zakładania drukarni itp.

Należy podkreślić, że stosunek do łaciny jako języka obcego nie tylko w wymiarze lingwistycznym, ale i kulturowym, był początkowo nawet wrogi, by z czasem ulec diametralnej zmianie. Przełom w postrzeganiu języka łacińskiego nastąpił w latach 30. XVII wieku, zaś wielką rolę w tym procesie odegrał Petro Mohyła oraz Kolegium Kijowsko-Mohylańskie, w którym łacina była językiem wiodącym. Język łaciński stał się również językiem kancelaryjnym Księstwa Halicko-Wołyńskiego, zaś po zawarciu Unii Lubelskiej jego znajomość stała się niemal koniecznością. Przejście ziem ukraińskich pod panowanie Litwy i Korony, pośrednictwo Polski w ,absorpcji” kultury antycznej, dały początek procesowi, który towarzyszył kulturze i językowi ukraińskiemu przez kolejne stulecia.

Jednakże rozważania na temat wpływu języków klasycznych na język ukraiński, rozumianego jako system, nie są celem sensu stricto proponowanego tekstu i stanowić będą jedynie tło dociekań. Głównym zadaniem artykułu jest próba odpowiedzi na pytania niewątpliwie wpisujące się w ten ogólny problem - mianowicie, w jakim zakresie i w jaki sposób języki grecki i łaciń-

\footnotetext{
D. Wieczorek, Украинский язык. Slavia Romana-Slavia Byzantina. Очерки по глагольности, Wrocław 1997, s. 8.
} 
ski są obecne w ukraińskiej terminologii mykologicznej, w szczególności zaś w obrębie oficjalnych nazw grzybów wielkoowocnikowych ${ }^{2}$, oraz w jakim stopniu języki klasyczne można traktować jako źródło tejże terminologii?

Język łaciński, jak i kultura antyczna, przenikały na tereny wschodniej Słowiańszczyzny szczególnie intensywnie w wieku XVII, zaś nauczanie łaciny, przekłady dzieł literackich, wykorzystywanie łacińskiej leksyki w procesie tworzenia terminologii naukowej wpływały na „książkowy” charakter zapożyczeń. Ich obecność i swoista infiltracja systemu leksykalnego języka ukraińskiego, a zwłaszcza podsystemów terminologicznych, jest niezaprzeczalna. To właśnie w połowie XVII wieku przybrał na sile proces, który w wielu dziedzinach nauki trwa nieprzerwanie do dzisiaj. Bez grecyzmów i latynizmów trudno wyobrazić dziś sobie ukraińską, ale rzecz jasna nie tylko ukraińską, terminologię medyczną, farmaceutyczną, prawną, biologiczną itp. Frekwencja terminów o proweniencji greckiej i łacińskiej jest zróżnicowana i w głównej mierze zależy od stopnia uzależnienia danego podsystemu od „klasycznej” bazy pojęciowej. Wyprzedzając ostateczne szczegółowe ustalenia wynikające z badań nad rolą i funkcjonowaniem grecyzmów i latynizmów w obrębie terminologii mykologicznej i nazewnictwa grzybów wielkoowocnikowych, należy podkreślić, że ich obecność w jej zasobach jest znacząca.

Geneza mykologii sięga czasów antycznych, a pierwszych prób opisu grzybów podejmowali się już w IV-III wieku p.n.e. Arystoteles czy Teofrast z Eresos. Z uwagi na niezwykle trudną materię badawczą i ciągłe odkrywanie nowych gatunków grzybów, prace nad ich klasyfikacją trwają nieprzerwanie do dziś. Pochylając się nad historią mykologii, można wyróżnić kilka okresów jej rozwoju, co ściśle związane jest z odkryciami wybitnych uczonych zajmujących się badaniami grzybów. Prace Remberta Dodoensa (XVI w.), Charlesa de l'Écluse (XVII w.), Karola Linneusza (XVIII w.), Christiaana Persoona (XVIII-XIX w.), Eliasa Friesa (XIX w.), jak i wielu innych biologów, botaników i mykologów (m.in. Guida Pontecorvo, Alexandra Fleminga, Karla Cejpa, Fredericka K. Sparrowa), także tych współczesnych (Geoffrey’a Clough Answortha, Guy'a Bisby'ego, Donalda Barra, Davida Hibbetta i in.) $)^{3}$, prócz tej samej materii badawczej łączy ważny aspekt: łacina - język, w którym powstawały obszerne rozprawy na temet grzybów, wreszcie język stanowiący podstawę nazewniczą dla opisywanych gatunków.

Działalność Ch. Persoona i E. Friesa sprzyjała popularyzacji mykologii. Pod ich wpływem w wielu krajach europejskich zaczęły powstawać „,szko-

\footnotetext{
2 Ukr. макроміцети: makros (gr.) - duży, mykes (gr.) - grzyb lub капелюшні, шапинкові гриби.

3 Д. Леонтьєв, О. Акулов, Загальна мікологія: Підручник для вищих навчальних закладів, Харків 2007.
} 
ły mykologiczne". Wyprawy badawcze mające na celu opisanie rodzimych gatunków grzybów organizowano również na terenach dzisiejszej Ukrainy. Prace Józefa Jundziłła, Wasyla Czerniajewa, Illi Borszczowa, Andrija Potebni, choć nie były napisane po ukraińsku, to jednak wniosły wiele do rozwoju ukraińskiej mykologii. Ukraińscy uczeni pracujący na przestrzeni ostatniego półwiecza, m.in. Marija Zerowa, Iryna Dudka, Sołomon Wasser, Nadija Mytropolska, Maryna Suchomłyn, Weronika Dżahan, popularyzując wiedzę na temat grzybów, w swych licznych pracach bazowali właśnie na terminologii opierającej się na łacinie bądź sami tworzyli terminy z jej wykorzystaniem.

Niezaprzeczalnym pozostaje fakt, iż języki klasyczne, będące istotnym elementem terminotwórczym w obrębie języka ukraińskiego, są obecne w ukraińskiej literaturze mykologicznej od samego początku i będą nadal w niej funkcjonować. Chcąc ocenić skalę tego zjawiska i choćby tylko zarysować ramy występowania terminologii mykologicznej o proweniencji greckiej i łacińskiej w pracach ukraińskich mykologów, należałoby dokonać wyboru źródeł, które posłużą za materiał badawczy pozwalający na wyciągnięcie wniosków. W miarę szerokie spectrum dla ekscerpcji materiału gwarantują opracowania akademickie z zakresu mykologii ${ }^{4}$, artykuły naukowe botaników, mykologów i językoznawców ${ }^{5}$, atlasy i słowniki poświęcone grzybom ${ }^{6}$ oraz strony internetowe o tematyce grzybiarskiej ${ }^{7}$. Jednakże eksplorację termino-

4 Zob. m.in. Д. Леонтьєв, О. Акулов, op. cit.; I. Костіков, В. Джаган, Е. Демченко, О. Бойко, В. Бойко, П. Романенко, Ботаніка. Водорості та гриби: Навчальний посібник, Київ 2006.

5 Zob. m.in. I. Беседіна, Історія досліджень та сучасний стан мікобіоти м. Полтави, [źródło internetowe:] http://dspace.pnpu.edu.ua/bitstream/123456789/3839/1/Besedina2.pdf [dostęp: 12.02.2018 r.]; В. Куриленко, Гриби - губи: полісемія чи омонімія? (на матеріалі лексики поліських говорів), „Записки з українського мовознавства”, вип. 16, Одеса 2006, s. 219-223; Н. Науменко, „Розхрабрувався гриб у саду...”: про один незвичайний рослинний образ украӥнської поезії. Віршознавчий семінар: з нагоди 90-річчя від дня народження Ігоря Качуровського, Київ 2009; Р. Омельковець, Мікологічна лексика західнополіських говірок, [w:] Современные направления теоретических и прикладных исследований” материалы международной научно-практической конференции, t. 23, Одесса 2013, s. 91-97; Р. Омельковець, Семантична трансформачія як спосіб номіначї̈ мікооб'єктів у західнополіських говірках, „Типологія та функції мовних одиниць”, nr 1, Луцьк 2014, s. 231239; В. Прус, «У нетрях прокидаються гриби. Магічний знак - по відьминому колу.» (етнолінгвістичний аспект поліського збиральництва), „Волинь-Житомирщина. Історико-філологічний збірник з регіональних проблем" 2001, nr 6, s. 151-153; I. Сабадош, Як звуться гриби?, „Культура слова” 1988, nr 34, s. 39-41; Л. Симоненко, Синонімічні назви грибів в украӥнській мові, „Рідне слово” 1973, nr 7, s. 23-26; Л. Симоненко, Як назвати гриби?, „Рідне слово” 1974, nr 9, s. 38-41; М. Ткачук, Мікономінація в чорнобильських говірках (питання реконструкиії ареалу), „Волинь - Житомирщина” 2010, nr 22, s. 275-282. 6 Zob. М. Сухомлин, В. Джаган, Гриби Украйни, Київ 2013; 3. Калинець-Мамчур, Словник-довідник з альгології та мікології, Львів 2011.

7 Zob. http://www.cybertruffle.org.uk/ukrafung/index.htm [dostęp: 12.02 .2018 r.], http://gri bi.net.ua/ [dostęp: 12.02 .2018 r.], https:/evshanzillya.wordpress.com/2011/09/16/\%D1 
logii funkcjonującej we wspomnianych zasobach pozostawiamy odrębnemu opracowaniu, skupiając się na analizie występujących tam oficjalnych nazw grzybów makroskopijnych pod kątem ich związków z językami klasycznymi, głównie zaś z łaciną.

Grzyby makroskopijne to sztucznie utworzona grupa niemająca odniesienia do pokrewieństwa ewolucyjnego. Głównym i zasadniczym kryterium jej klasyfikacji jest wielkość owocnika (gatunki o rozmiarach owocnika powyżej $2 \mathrm{~mm}$ ), a zatem jedna $\mathrm{z}$ cech użytkowych ${ }^{8}$ (obok np. smaku owocnika, jego zapachu, kształtu itp.), nie zaś taksonomicznych. Warunek odpowiedniego rozmiaru spełniają owocniki niektórych gatunków grzybów należących do dwóch jednostek - workowców (аскомікотові гриби) i podstawczaków (базидієві гриби).

Botanicy i mykolodzy szacują, że na świecie istnieje ok. dwóch milionów gatunków grzybów. Dotąd poznano i opisano niespełna 100 tys. z nich. Ułamek tej liczby stanowią grzyby wielkoowocnikowe, z czego na Ukrainie występuje ich ok. 5 tys. gatunków.

Analizę oficjalnych ${ }^{9}$ ukraińskich nazw grzybów makroskopijnych pod kątem greckiej/łacińskiej motywacji nazw przeprowadzono w oparciu o słownik Zwenysławy Kałyneć-Mamczur, atlas grzybów autorstwa Maryny Suchomłyn i Weroniki Dżahan oraz indeksy grzybów występujących na Ukrainie zamieszczone na stronach http://gribi.net.ua i http://www.cybertruffle.org.uk/ ukrafung/ukr/index.htm.

Nazwa gatunkowa grzyba to struktura składająca się zwykle z dwóch elementów - tworzą ją człon rodzajowy oraz epitet gatunkowy. Schemat ten jest obowiązujący zarówno dla nazwy łacińskiej, jak i ukraińskiej (np. Cerioporus stereoides - Церionop стереоідний). Na gruncie mykologii łacińskie nazwy gatunkowe grzybów w większości przypadków stanowią bazę do tworzenia nazw w obrębie innych struktur językowych. Najczęściej stosowanym zabiegiem jest transfer bezpośredni nazwy gatunkowej (zwykle przy uwzględnie-

\%97\%D1\%81\%D1\%82\%D1\%96\%D0\%B2\%D0\%BD\%D1\%96-\%D0\%B3\%D1\%80\% D0\%B 8\%D0\%B1\%D0\%B8-\%D1\%83\%D0\%BA\%D1\%80\%D0\%B0\%D1\%97\%D0\%BD\%D0\%B8/ [dostęp: 12.02.2018 r.], http://ua.griby.org.ua/naibilsh-poshyreni-gryby/ [dostęp: 12.02 .2018 r.], http://old.geology.lnu.edu.ua/phis_geo/fourman/Grybus\%20in $\% 20$ the $\% 20$ our $\% 20$ forests/ mushr.htm [dostęp: 12.02.2018 r.], https://decor-garden.com.ua/gribi/index.php.htm [dostęp: 12.02.2018 r.], https://pl.wikipedia.org/wiki/Binominalne_nazewnictwo_gatunk $\% \mathrm{C} 3 \% \mathrm{~B} 3 \mathrm{w}$ [dostęp: $12.02 .2018 \mathrm{r}$.].

Więcej na temat klasyfikacji semantycznej uwzgledniającej cechy użytkowe grzybów zob. P. Jóźwikiewicz, Oficjalne nazwy ukraińskich i polskich grzybów jadalnych - klasyfikacja znaczeniowa, „Roczniki humanistyczne” 2016, z. 7, s. 201-217.

9 Nazewnictwo grzybów to dość złożona kwestia. Nieodosobnione są przypadki, gdy jeden gatunek grzyba ma nawet do kilkudziesięciu łacińskich synonimów naukowych; nazwa oficjalna grzyba częstokroć nie jest jedyną, należy dodać tu jeszcze nazwy regionalne, ludowe, niekiedy również bardzo liczne i zróżnicowane. 
niu koniecznych zmian na poziomie fonetycznym) bądź kalkowanie wszystkich lub pojedynczych jej elementów. Kwestią do rozstrzygnięcia pozostaje to, w jakim stopniu taki właśnie schemat nazewniczy realizowany jest w obrębie ukraińskich nazw grzybów makroskopijnych.

Na potrzeby niniejszego artykułu weryfikacji poddano 1686 nazw gatunkowych grzybów makroskopijnych występujących na Ukrainie i zaliczanych do trzech grup użytkowych: grzyby jadalne, niejadalne oraz trujące.

Analiza materiału źródłowego pozwala stwierdzić, iż większość ukraińskich nazw grzybów tworzą skupienia terminologiczne realizujące się w postaci modelu $(\mathrm{N}+$ Adj) lub $(\mathrm{N}+$ Part $)$, incydentalnie $($ Adj $+\mathrm{N})$. Rzadkością są nazwy jednoelementowe $(\mathrm{N})$, jednak w tym przypadku mamy do czynienia przede wszystkim $\mathrm{z}$ mechanizmem polegającym na przeniesieniu nazwy regionalnej, ludowej do terminologii oficjalnej (гірчак, зелениця, ковпак, лускач itd.). Jak wynika z poniższego zestawienia, większość ukraińskich konstrukcji atrybutywnych obecnych w analizowanym materiale w jakimś stopniu bazuje na zasobach leksykalnych języków klasycznych, przede wszystkim na łacinie. Nazwy powstałe przy wykorzystaniu rodzimych ukraińskich zasobów leksykalnych, a przy tym zupełnie nieodnoszące się do nazwy łacińskiej, stanowią względnie liczną grupę, jednak ich udział w próbce przekroczył zaledwie granicę 10\% (12,6\% ogółu analizowanych mykonimów, 210 nazw), np.:

$\begin{array}{ll}\text { Amanita muscaria } & \text { Мухомор червоний } \\ \text { Armillaria mellea } & \text { Опеньок справжній } \\ \text { Boletus edulis } & \text { Білий гриб } \\ \text { Bovista pila } & \text { Порхавка шапкова } \\ \text { Cantharellus cibarius } & \text { Лисичка звичайна }\end{array}$

Większość ukraińskich oficjalnych nazw grzybów makroskopijnych to struktury dwuelementowe będące zupełną lub fragmentaryczną kopią łacińskiej gatunkowej nazwy grzyba (źródłosłowy typowo greckie są relatywnie rzadkie, w badanym materiale znacznie ustępują łacińskim, np. Chrysomphalina chrysophylla - Хрізомфаліна золотистолиста, Octospora huтоsa - Октоспора гумусова i in.), a sam stopień i zakres przeniesienia łacińskich nazw grzybów na grunt języka ukraińskiego jest dość zróżnicowany. Zatem uwzględniając ten właśnie czynnik, ukraińskie mykonimy oznaczające nazwy gatunkowe grzybów można zakwalifikować do kilku grup będących odzwierciedleniem ich łacińskiej etymologii.

Za podstawę kwalifikacji do odpowiedniej grupy przyjęto charakter członu rodzajowego, natomiast $\mathrm{w}$ obrębie grupy zaliczenie do właściwej podgrupy uzależnione było od typu epitetu gatunkowego. $\mathrm{Z}$ proponowanego podziału wyłączono nazwy składające się z dwóch leksemów ukraińskich jako niespełniających założenia o łacińskim pochodzeniu. 


\section{Człon rodzajowy: zapożyczenie właściwe}

Opisany w czterech podgrupach minikorpus leksykalny bazujący na zapożyczeniach jako elementach głównych nazw grzybów, ma największą reprezentację w obrębie badanej próbki i stanowi 75\% ogółu występujących w niej jednostek nazewniczych.

\subsection{Zapożyczenie właściwe + zapożyczenie właściwe}

Charakterystyczne dla ukraińskiego słownictwa mykologicznego, zwłaszcza zaś dla samych nazw gatunkowych grzybów, są formacje składające się wyłącznie $\mathrm{z}$ elementów zapożyczonych $\mathrm{w}$ postaci niezmodyfikowanej ${ }^{10}$ lub zmienionej nieznacznie, co jest podyktowane cechami fonetycznymi języka ukraińskiego. Na 1686 jednostek współtworzących analizowaną próbkę, nazwę gatunkową grzyba składającą się z dwóch zapożyczeń właściwych (nazwa rodzajowa + epitet gatunkowy) tworzy tylko 11 mykonimów ( $0,65 \%$ próbki), np.:

Anthracobia maurilabra ${ }^{11}$
Ascocoryne cylichnium
Entoloma niphoides
Nectria peziza
Postia ptychogaster

Wśród struktur przeszczepionych na grunt języka ukraińskiego bez żadnych niemal zmian na płaszczyźnie fonetycznej obecne są również nazwy łacińskie, w których epitety gatunkowe to zlatynizowane antroponimy zwykle oznaczające nazwiska biologów, botaników czy mykologów. W badanym materiale zanotowano 69 nazw tego typu (4,1\% ogółu analizowanych mykonimów), np.:
Brunneoporus kuzyanus
Cabalodontia queletii
Camarophyllopsis schulzeri
Cinereomyces lindbladii
Collybia cookei

Антракобія маурілабра
Аскокоріне циліхніум
Ентолома ніфоіде
Нектрія пеціца
Постія птихогастер

Кабалодонція Келе

Камарофіллопсис Шульцера

Цінереоміцес Ліндблада

Колібія Кука
Бруннеопор Кузіана

\subsection{Zapożyczenie właściwe + hybryda}

Zauważalną grupę (58 przykładów, czyli 3,45\% próbki) wśród nazw grzybów tworzą mykonimy, których człony rodzajowe są zapożyczeniami właś-

\footnotetext{
10 Przejście z alfabetu łacińskiego na cyrylicę uznaję za oczywiste.

$11 \quad$ Z uwagi na ograniczenia wydawnicze dla każdej z grup podano po pięć przykładów; mniejsza liczba przykładów w podgrupie jest rzeczywistym zbiorem nazw danego typu w badanej próbce.
} 
ciwymi, epitety gatunkowe natomiast - hybrydami, przymiotnikami o obcej podstawie słowotwórczej i ukraińskim elemencie asymilującym, np.:

Astraeus hygrometricus

Athelia teutoburgensis

Botryohypochnus isabellinum

Coriolopsis gallica

Crepidotus autochthonus
Астрей гігрометричний

Ателія тевтобурзька

Ботріохіпохнус ізабелловий

Коріолопсис гальський

Крепідот автохтонний

Proces adaptacji morfologicznej zachodzi najczęściej przy udziale cząstek $^{12}$-ичн-, -ов-, -ськ-, rzadziej -зьк-, -н-.

\subsection{Zapożyczenie właściwe + kalka/półkalka}

Cechą charakterystyczną ukraińskich nazw grzybów jest to, iż w funkcji epitetów gatunkowych dość często występują struktury będące kalkami lub półkalkami łacińskich pierwowzorów. W analizowanym materiale obecne są zarówno złożenia przymiotnikowe niewspółrzędne, jak i złożenia współrzędne oraz zestawienia, np.:

Chlorophyllum agaricoides

Hericium coralloides

Auriculariopsis albomellea

Baeospora myosura

Cheilymenia theleboloides

\begin{abstract}
Хлорофіллум агариковидний Геріцій коралоподібний

Аурикулариопсис блідо-медовий

Беоспора мишехвоста

Хейліменія телеболовидна
\end{abstract}

W ten typ konstrukcji wpisują się również mykonimy, których człon rodzajowy jest strukturą powstała na bazie zlatynizowanej nazwy własnej, np. Badhamia macrocarpa - Бадгамія великоплідна, Jackrogersella multiformis - Джекрожерселла багатолика itp. Nazw o prezentowanej budowie jest w tej grupie 375 (22,2\% ogółu analizowanych mykonimów).

\subsection{Zapożyczenie właściwe + leksem ukraiński}

Analizowany model odznacza się największą liczbą struktur (752 przykłady, czyli 44,6\% próbki). Tworzą ją zapożyczenia właściwe (człon konstytutywny skupienia imiennego) oraz elementy ukraińskie uzupełniające dwuczłonową konstrukcję atrybutywną, np.:
Antrodia macra
Антродія вербова
Calocera viscosa
Калоцера клейка
Clitocella mundula
Клітоцелла гірка

\footnotetext{
12 W przypadku struktur hybrydalnych trudno mówić o derywatach, a co za tym idzie również i o sufiksach. Przymiotniki współtworzące nazwę gatunkową grzyba powstają w wyniku asymilacji wyrazów obcych, brak tu motywacji słowotwórczej, a zatem wymienione cząstki pełniące jedynie funkcję strukturalną nie powinny być utożsamiane z sufiksami.
} 
Coccomyces tumidus

Conocybe blattaria
Кокоміцес роздутий

Коноцибе коричнево-охряна

Znamiennym jest fakt, że wśród nazw o opisywanej strukturze niezwykle liczne są mykonimy, których człon akcesoryczny jest wiernym lub niemal wiernym odpowiednikiem łacińskiego oryginału:

Agrocybe arvalis

Albatrellus ovinus

Antrodia heteromorpha

Brefeldia maxima

Cerioporus mollis
Агроцибе польова

Альбатрел овечий

Антродія мінлива

Брефельдія найбільша

Церіопор м'який

Na uwagę zasługują struktury charakterystyczne zwłaszcza dla szeroko rozumianego nazewnictwa biologicznego, do którego zaliczamy przecież omawiane zasoby leksykalne. Wiele nazw grzybów zawiera elementy wskazujące na odkrywcę danego gatunku lub osobę zasłużoną dla świata nauki. W przeciwieństwie do opisanych wyżej mykonimów (typu Cystolepiota bucknallii - Цистолепіота Букналла), w przypadku których nazwa własna pełniła rolę epitetu gatunkowego, w konstrukcjach prezentowanych poniżej nazwy własne zajmują pozycję członu rodzajowego. Są to zlatynizowane leksemy wywodzące się z języków nowożytnych, a następnie $\mathrm{w}$ tejże postaci adaptowane na gruncie języka ukraińskiego, np.:

Bjerkandera fumosa

Heyderia abietis

Holwaya mucida

Kretzschmaria deusta

Junghuhnia collabens
Б’еркандера димчаста

Хейдерія ялинова

Голвайя слизиста

Кречмарія спалена

Юнгхунія зімнята

Przedstawiona grupa ukraińskich nazw grzybów wielkoowocnikowych, których członem głównym były zapożyczenia właściwe wywodzące się z języka łacińskiego, odznacza się w badanej próbce dużą frekwencyjnością. Łączna liczba konstrukcji, których człon rodzajowy został zapożyczony, to 1265 jednostek (75\% ogółu analizowanych mykonimów).

\section{Człon rodzajowy: hybryda}

W badanym materiale obecny jest w zasadzie jeden przykład ilustrujący model, w którym człon rodzajowy ma postać struktury hybrydalnej. Пop $p u-$ ровик червоноспоровий (Porphyrellus porphyrosporus) to nazwa, której nadrzędnik utworzony został na bazie greckiego rdzenia i ukraińskiego elementu -овик (choć możliwa jest tu również inna interpretacja - leksem порфировик może być rezultatem klasycznej derywacji odprzymiotnikowej порфиров-ик 
$\leftarrow$ порфировий). Drugim przykładem ilustrującym tę grupę jest Кальмарник веретеноподібний (кальмар-ник $\leftarrow$ кальмар), jednak grecko-łacińska nazwa grzyba, a raczej człon rodzajowy (Pseudocolus fusiformis), nie stał się bazą do bezpośredniego utworzenia nazwy ukraińskiej.

\section{Człon rodzajowy: leksem ukraiński}

Ukraińskie nazwy grzybów, których człon rodzajowy ma postać leksemu etymologicznie ukraińskiego, są drugim pod względem liczebności zbiorem w obrębie analizowanej próbki (186 elementów, czyli 11\% próbki).

\subsection{Leksem ukraiński + zapożyczenie właściwe}

Prezentowana grupa, w której funkcję członu rodzajowego pełnią rzeczowniki właściwe dla języka ukraińskiego, pod względem formy epitetu gatunkowego jest w zasadzie jednorodna. Struktury tego typu obecne w analizowanym materiale to nazwy własne przeniesione bez większych modyfikacji $\mathrm{z}$ łacińskiego pierwowzoru, np.:

Agaricus benesii

Butyriboletus fechtneri

Coprinopsis patouillardii

Cortinarius bulliardii

Phallus hadriani
Печериця Бенеша Боровик Фехтнера Гнойовик Патуйяра Павутинник Бюлляра Веселка Адріана

Występowanie mykonimów tego typu jest dość ograniczone, w materiale egzemplifikacyjnym znajdują się 34 takie struktury ( $2 \%$ ogółu analizowanych mykonimów).

\subsection{Leksem ukraiński + hybryda}

Na podobnym poziomie (27 przykładów, czyli 1,6\% próbki) rysuje się liczebność konstrukcji, w których członem akcesorycznym skupienia imiennego jest hybryda: przymiotnik powstały w oparciu o obcy rdzeń (łaciński lub grecki) i ukraińską cząstkę (zwykle -альн-, -н-, -ов-, -ев- (-св-), -ськ-), np.:

Amanita pantherina

Amanita porphyria

Calvatia gigantea

Cortinarius triumphans

Russula pelargonia
Мухомор пантерний

Мухомор порфировий

Головач гігантський

Павутинник тріумфальний

Сироїжка пеларгонієва

\subsection{Leksem ukraiński + kalka}

Dość liczną grupę (125 przykładów, a więc 7,4\% próbki) pośród ukraińskich nazw grzybów makroskopijnych tworzą konstrukcje, na które składają 
się leksemy ukraińskie (człon rodzajowy) oraz kalki/półkalki językowe reprezentowane zarówno przez złożenia przymiotnikowe niewspółrzędne (z nadrzędnikami rzeczownikowymi lub przymiotnikowymi), jak i złożenia przymiotnikowe współrzędne, np.:

Agaricus bitorquis

Agaricus xanthodermus

Amanita ovoidea

Calvatia cyathiformis

Coprinopsis echinospora
Печериця двокільцева

Печериця жовтошкіра

Мухомор яйцеподібний

Головач келиховидний

Гнойовик шипастоспоровий

W obrębie badanego materiału napotkać można również struktury, których „kalkowany” epitet gatunkowy jest jukstapozycją, np. Cortinarius alborufescens - Павутинник біло-рудіючий, Cortinarius rufoolivaceus - Павутинник рудо-оливковий itp.

Pomimo tego, że opisana grupa, w której funkcję członu rodzajowego pełniły leksemy ukraińskie, jest druga pod względem liczebności przykładów, to jednak znacznie ustępuje strukturom opisanym w punkcie 1 .

\section{Człon rodzajowy: kalka/pólkalka}

Ostatnią grupę nazw, w przypadku których choćby jeden z elementów utworzony został na bazie łaciny lub greki, tworzą struktury powstałe w wyniku kalkowania członu rodzajowego mykonimu. Mała liczba przykładów (23 skupienia, czyli 1,3\% ogółu analizowanych mykonimów) ilustrująca opisywany tu model świadczy o tym, że ten sposób tworzenia ukraińskich nazw rodzajowych dla grup grzybów nie jest w tym przypadku produktywny i ogranicza się w zasadzie do pięciu rodzajów grzybów (білогнойовик, білопавутинник, білопечериця, чорнопластинник, шишкогриб), nр.:

Leucoagaricus moseri

Leucocoprinus badhamii

Leucoagaricus americanus

Leucocortinarius bulbiger

Leucoagaricus nympharum

Leucoagaricus carneifolius

Strobilomyces strobilaceus

Melanophyllum haematospermum
Білопечериця Мозера

Білогнойовик Бедхема

Білопечериця американська

Білопавутинник бульбистий

Білопечериця дівоча

Білопечериця тілеснопластинкова

Шишкогриб лускатоніжковий

Чорнопластинник

криваво-червоний

Formy epitetów gatunkowych powyższych przykładów są adekwatne do ustaleń w pozostałych grupach (zapożyczenia - Білопечериия Мозера, leksemy ukraińskie - Білопечериия дівоча, hybrydy - Білопечериия американська, kalki - Білопечериия тілеснопластинкова). 
W funkcji członów rodzajowych niezwykle rzadko występują leksemy będące półkalkami. W analizowanej próbce znajduje się jedynie kilka takich struktur (Pseudocraterellus undulatus - Псевдолійочник хвилястий, Рsеиdohydnum gelatinosum -Псевдоӥжовик драглистий, Pseudotricholoma metародіuт - Псевдорядовка блідо-червонувата).

Analiza ukraińskich nazw grzybów makroskopijnych, której wyniki przedstawiono w niniejszym tekście, dowodzi, iż wpływ, zwłaszcza łaciny, na ten kompleks słownictwa jest znaczący.

Aż 75\% nazw w badanej próbce (1265 nazw) tworzą struktury, których element główny to zapożyczenie właściwe o proweniencji głównie łacińskiej. Nazw, na człon rodzajowy których składał się leksem ukraiński, było ponad trzykrotnie mniej (wliczając w to nawet konstrukcje, których oba człony były stricte ukraińskie). Zupełnie odmiennie rysuje się struktura epitetów gatunkowych. Badania dowiodły, że tu z kolei dominują leksemy rdzennie ukraińskie (w sumie niemal tysiąc jednostek, czyli ok. 55\% ogółu badanych mykonimów) i kalki (ponad 500 jednostek, czyli ok. 30\% próbki). W funkcji tej zapożyczenia występują raczej incydentalnie (powyżej stu jednostek), podobnie jak struktury hybrydalne (kilkadziesiąt przykładów).

Odpowiadając na pytanie postawione w pierwszej części artykułu, trzeba podkreślić, że języki klasyczne są bardzo ważnym rezerwuarem dla ukraińskiej terminologii mykologicznej, a w szczególności dla analizowanych tu nazw grzybów makroskopijnych. Tendencja do wykorzystywania szczególnie języka łacińskiego w celach nazewniczych przez ukraińskich mykologów, botaników i biologów jest powszechna. Pamiętać należy, że procesy terminotwórcze w tej dziedzinie, z uwagi na dynamikę rozwoju samej mykologii, trwać będą jeszcze bardzo długo. Ważnym jest, by język ukraiński nie uległ przy tym zmarginalizowaniu. W procesie tworzenia oficjalnych nazw grzybów ukraińszczyzna pełni jak na razie głównie funkcje „pomocnicze" (zajmując pozycję epitetów gatunkowych); stwierdzenie to nie dotyczy nazw regionalnych, ludowych, które sporadycznie przenikają do oficjalnego nazewnictwa mykologicznego.

Konkludując, należy stwierdzić, iż języki klasyczne będące istotnym elementem terminotwórczym w obrębie języka ukraińskiego „współtworzą” ukraińską terminologię mykologiczną, stając się jej kluczowym pierwiastkiem. Biorąc jednak pod uwagę zagrożenia $\mathrm{z}$ tego faktu płynące, a więc możliwość marginalizacji języka ukraińskiego, wypada tendencję tę uznać za dość niepokojącą. 


\section{BIBLIOGRAFIA}

Besedìna İrina. 2008. İstoriâ doslìžen'ta sučasnijstan mikobiotim. Poltaviû. W: http://dspace.pnpu.edu.ua/bitstream/123456789/3839/1/Besedina2.pdf [dostęp: 12.02.2018 r.]. [Беседіна Ірина. 2008. Історія досліджень та сучасний стан мікобіоти м. Полтавию. W: http://dspace.pnpu.edu.ua/bitstream/123456789/3839/1/Besedina2.pdf [dostęp: 12.02.2018 r.].

Jóźwikiewicz Przemysław. 2016. Oficjalne nazwy ukraińskich i polskich grzybów jadalnych - klasyfikacja znaczeniowa. „Roczniki humanistyczne” LXIV, zeszyt 7: 201217.

Kalinec'-Mamčur Zvenislava. 2011. Slovnik-dovidnik z al'gologï ta mikologiï. L'vìv: L'vìvs'kij nacìonal'nij unìversitet ìm. İvana Franka [Калинець-Мамчур Звенислава. 2011. Словник-довідник з альгології та мікології. Львів: Львівський національний університет ім. Івана Франка].

Kostìkov İgor, Džagan Veronìka, Demčenko Eduard, Bojko Ol'ga, Bojko Viktorìâ, Romanenko Petro. 2006. Botanika. Vodorostita gribi: Navčal'nij posibnik. Kiïv: Arìstej [Костіков Ігор, Джаган Вероніка, Демченко Едуард, Бойко Ольга, Бойко Вікторія, Романенко Петро. 2006. Ботаніка. Водорості та гриби: Навчальний посібник. Київ: Арістей].

Kurilenko Volodimir. 2006. Gribi - gubi: polisemiâ či omonimiâa? (na materialì leksiki polis'kih govoriv). „Zapiski z ukraïns'kogo movoznavstva” vip. 16: 219-223 [Куриленко Володимир. 2006. Гриби - губи: полісемія чи омонімія? (на матеріалі лексики поліських говорів). ,Записки з українського мовознавства” вип. 16: 219-223].

Leont'êv Dmitro, Akulov Oleksandr. 2007. Zagal'na mikologiâ: Pidručnik dlâ višihnavčal'nih zakladiv. Harkìv: Vid. grupa «Osnova» [Леонтьєв Дмитро, Акулов Олександр. 2007. Загальна мікологія: Підручник для вищих навчальних закладів. Харків: Вид. група «Основа»].

Naumenko Nataliâ. 2009. „, Rozhrabruvavsâ grib u sadu... ”: pro odin nezvičajnij roslinnij obraz ukraïns'koï poeziï. W: Viršoznavčij seminar: z nagodi 90-riččĉa vid dnâ narodžennâ İgorâ Kačurovs'kogo: zb. nauk. pr., Kiïv: „VPC Kï̈vs'kij unìversitet” [Науменко Наталія. 2009. „Розхрабрувався гриб у саду...”: про один незвичайний рослинний образ української поезії. W: Віршознавчий семінар: з нагоди 90-річчя від дня народження Ігоря Качуровського: зб. наук. пр., Київ: „ВПЦ Київський університет"].

Omel'kovec' Ruslana. 2013. Mikologična leksika zahidnopolìs'kih govìrok. „Sovremennye napravleniâ teoretičeskih i prikladnyh issledovanij: materialy meždunarodnoj naučnopraktičeskoj konferencii” Т. 23: 91-97 [Омельковець Руслана. 2013. Мікологічна лексика західнополіських говірок. „Современные направления теоретических и прикладных исследований: материалы международной научно-практической конференции" Т. 23: 91-97].

Omel'kovec' Ruslana. 2014. Semantična transformaciâ âk sposib nominaciï mikoob 'êktìv u zahidnopolis'kih govirkah. „Tipologiâ ta funkciï movnih odinic"” nr 1: 231-239 [Омельковець Руслана. 2014. Семантична трансформація як спосіб номінації мікооб'єктів у західнополіських говірках. „Типологія та функції мовних одиниць” $\mathrm{nr}$ 1: 231-239].

Prus Valentina. 2001. "U netrâh prokidaût'sâ gribi. Magičnij znak-povid'minomu kolu» (etnolìngvističnij aspekt polis'kogo zbiral'nictva). „Volin'-Žitomirŝina. İstorikofillologičnij zbìrnik zregìonal'nih problem” nr 6: 151-153 [Прус Валентина. 2001. «У нетрях прокидаються гриби. Магічний знак - по відьминому колу» (етно- 
лінгвістичний аспект поліського збиральництва). „Волинь-Житомирщина. Історико-філологічний збірник з регіональних проблем" $\mathrm{nr}$ 6: 151-153].

Sabadoš Ìvan. 1988. Âk zvut'sâ gribi? „Kul'tura slova” Vip. 34: 39-41 [Сабадош Іван. 1988. Як звуться гриби? „Культура слова” Вип. 34: 39-41].

Simonenko Lûdmila. 1973. Sinonimičnì nazvi gribìv v ukrä̈ns'kì movì. „Rìdne slovo” vip. 7: 23-26 [Симоненко Людмила. 1973. Синонімічні назви грибів в украӥнській мові. „Рідне слово” вип. 7: 23-26].

Simonenko Lûdmila. 1974. Âk nazvati gribi? „Rìdne slovo” vip. 9: 38-41 [Симоненко Людмила. 1974. Як назвати гриби? „Рідне слово” вип. 9: 38-41].

Suhomlin Marina, Džagan Veronika. 2013. Gribi Ukraïni., Kiïv: Vidavnictvo «Kraïna mrìj» [Сухомлин Марина, Джаган Вероніка. 2013. Гриби України. Київ: Видавництво «Країна мрій»].

Tkačuk Marina. 2010. Mikonominaciâ v čornobil's'kihgovirkah (pitannâ rekonstrukciï arealu). „Volin' - Žitomirŝina” nr 22 (2): 275-282 [Ткачук Марина. 2010. Мікономінація в чорнобильських говірках (питання реконструкиії ареалу). „Волинь Житомирщина" nr 22 (2): 275-282].

Wieczorek Diana. 1997. Украинский язык. Slavia Romana - Slavia Byzantina. Очерки по глагольности. Wrocław: Wydawnictwo Uniwersytetu Wrocławskiego.

\title{
ЕНТОЛОМА НІФОІДЕ ОR ВЕСЕЛКА ЗВИЧАЙНА? LATIN AND GREЕK AS THE SOURCE OF UKRAINIAN NAMES OF MACROSCOPIC FUNGI
}

\begin{abstract}
This article discusses classical languages as an important source of Ukrainian mycological terminology and the names of macroscopic fungi. Research results presented in this article prove that the influence of classical languages, especially Latin, on this vocabulary is extensive. As many as $75 \%$ of names in the sample studied are structures whose main element is a loanword of mainly Latin provenance (e.g. Нектрія пеціиа). Names of which the generic element was created by the Ukrainian lexeme occurred three times less often (including even constructions, both of which were strictly Ukrainian, for example, Маслюк звичайний). The structure of species epithets is completely different. Here, in turn, the dominant lexemes are Ukrainian (almost a thousand units in total, such as Антродія вербова) and calques (over 500 units, e.g. Головач келиховидний). In this role, loanwords occur only in a select few cases (slightly above one hundred units, for example, Сироїжка Аврора), similarly to hybrid structures (just dozens of examples, e.g. Дощуовик умбровий).
\end{abstract}

Keywords: the Ukrainian language, Latin, Greek, mycological terminology, names of macroscopic fungi

\section{ЕНТОЛОМА НІФОІДЕ ЧИ ВЕСЕЛКА ЗВИЧАЙНА? ЛАТИНСЬКА І ГРЕЦЬКА МОВИ ЯК ДЖЕРЕЛО УКРАЇНСЬКИХ НАЗВ МАКРОСКОПІЧНИХ ГРИБІВ}

Анотація. Класичні мови - це важливе джерело української мікологічної термінології та аналізованих у цій статті офіційних назв макроскопічних грибів. Результати досліджень, які тут представлено, вказують, що вплив зокрема латинської мови на цю лексику превеликий. Майже 75\% проаналізованих назв це структури, головний 
член яких запозичення з латини (напр. Нектрія пеціца). Назв грибів, яких назву роду утворює українська лексема втричі менше (враховуючи й конструкції, яких оба члени були суто українськими, напр. Маслюк звичайний). Зовсім по-іншому виглядає структура дескрипторів виду. Тут переважають українські лексеми (майже тисяча одиниць, напр. Антродія вербова) і мовні кальки (більше 500 назв, напр. Головач келиховидний). У цій функції запозичення (більше ста назв, напр. Сироїжка Аврора) та гібриди (кількадесят прикладів, напр. Дощовик умбровий) виступають маргінально.

Ключові слова: українська мова, латинська і грецька мови, мікологічна термінологія, назви макроскопічних грибів 